\title{
Enhanced Oil Recovery by Using Solar Energy: Case Study
}

\section{Peter Jenkins ${ }^{1 *}$, Monaem Elmnifi ${ }^{2}$, Abdalfadel Younis ${ }^{3}$, Alzaroog Emhamed ${ }^{4}$, Naiema Amrayid5, Moneer Alshilmany6, Mohammed Alsaker ${ }^{7}$}

\author{
${ }^{1}$ Department of Mechanical Engineering, University of Colorado, Denver, USA \\ ${ }^{2}$ Department of Mechanical Engineering, Bright Star University, Ajdabiya, Libya \\ ${ }^{3}$ Department of Mechanical Engineering, University of Omar Al-Mukhtar, Al-Bayda, Libya \\ ${ }^{4}$ Department of Electrical Engineering, Bright Star University, Ajdabiya, Libya \\ ${ }^{5}$ Computer Department, Sirte University, Sirte, Libya \\ ${ }^{6}$ General Electric Company, Al-Marj, Libya \\ ${ }^{7}$ Department of Chemical Engineering, Bright Star University, Ajdabiya, Libya \\ Email: ^Peter.jenkins@ucdenver.edu, Monm.hamad@yahoo.co.uk, Abdalfadel.younis@omu.edu.ly
}

How to cite this paper: Jenkins, P., Elmnifi, M., Younis, A., Emhamed, A., Amrayid, N., Alshilmany, M. and Alsaker, M. (2019) Enhanced Oil Recovery by Using Solar Energy: Case Study. Journal of Power and Energy Engineering, 7, 57-67.

https://doi.org/10.4236/jpee.2019.76004

Received: April 18, 2019

Accepted: June 24, 2019

Published: June 27, 2019

Copyright $\odot 2019$ by author(s) and Scientific Research Publishing Inc. This work is licensed under the Creative Commons Attribution International License (CC BY 4.0).

http://creativecommons.org/licenses/by/4.0/

\begin{abstract}
This study investigates the steam generating potential of a solar steam generation system and the potential for utility scale implementation in Libya oil for steam demanding enhanced oil recovery (EOR) methods. The proposed system uses parabolic troughs as solar collectors. The technology is proved to be technically feasible. Solar EOR should be seen as an add-on to existing plants due to the abundance of solar energy in Libya. The System Advisor Model (SAM) model system, developed by the National Office of Renewable Energy (NRE), was used to assess the plant's active and economic performance.
\end{abstract}

\section{Keywords}

Glass Point, Steam, Solar Energy, Libya, Oil Recovery

\section{Introduction and Background}

In the context of climate change, the world is facing an increasing need to become more environmentally sustainable by seeking alternative and renewable sources of energy beyond conventional fossil fuels. Utilizing renewable energy sources such as wind, bio, hydro, solar, and geothermal energy is therefore pertinent in order to reach sustainability goals globally. Within the field of solar power, the most well-known technology is arguably Photovoltaic cells (PV), however there are several other usable technologies in this field. One such technology, which has received more attention as of late and which has recently be- 
come commercialized is concentrating solar thermal energy [1] [2]. This technology is conventionally used to produce thermal energy; however, this paper investigates the viability of solar thermal energy to produce steam that can be generated by recycling the underground water that accompanies processes of oil extracting. Most commonly, solar thermal energy plants are situated in warm areas with a high solar irradiance. The oil sands are oil reservoirs containing oil in the form of bitumen with a low permeability. In order to extract the bitumen, which has a high viscosity, situated at depths of lower than 25 meters, enhanced oil recovery methods are used to lower the viscosity of the oil making it easier to extract [3] [4]. The utilization of concentrating solar technology for steam production in enhanced oil recovery (EOR) has been proven in different places in the world. In Amal, Oman, a $7 \mathrm{MW}$ thermal parabolic trough steam production plant for EOR has been in operation since 2013 and in California, USA, a 29 MW thermal solar tower steam production plant for EOR was operational from 2011 to 2014 [5] [6] [7]. Steam flooding is a process whereby steam is injected into a number of wells while the oil is produced from adjacent wells, as shown in Figure 1. For generating steam or hot water, solar energy can be used for sustainability with a direct solar heating system [8] [9].

\subsection{Utility Scale System}

Libya's economy is largely built on the oil and gas industry, and the economic well-being of the province depends heavily on maintaining a steady level of oil production. The industry is based on oil deposits in the sand in the northern, southern and western parts of the country. The oil fields of Libya are shown in Figure 2. Moreover, the oil industry in Libya is affected by fluctuations in oil prices in the global oil market, and low oil prices are devastating to the country's economy. The recent low oil prices have negatively affected many oil companies in Libya, but industries that consume oil instead of producing it thrive. For example, the plastics industry and the rest of the petroleum industries are investigating ways to invest their surplus. Enhanced solar thermal recovery could be a good and economical alternative. In this paper, the possibility of implementation of the solar steam generation system is shown on utility scale and extraction techniques that can be used.

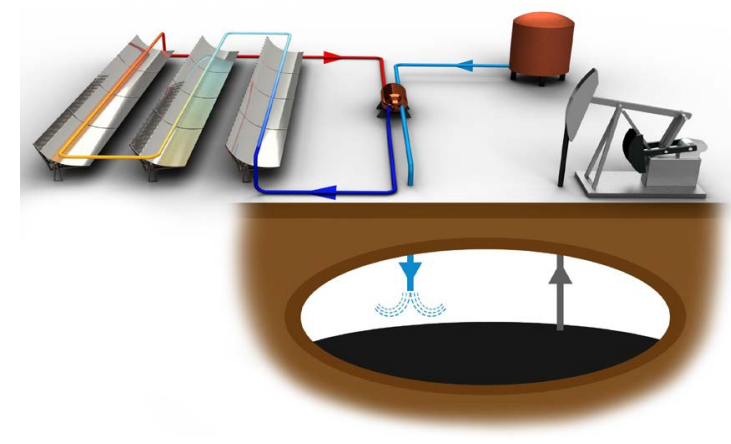

Figure 1. Solar enhanced oil recovery (EOR). 


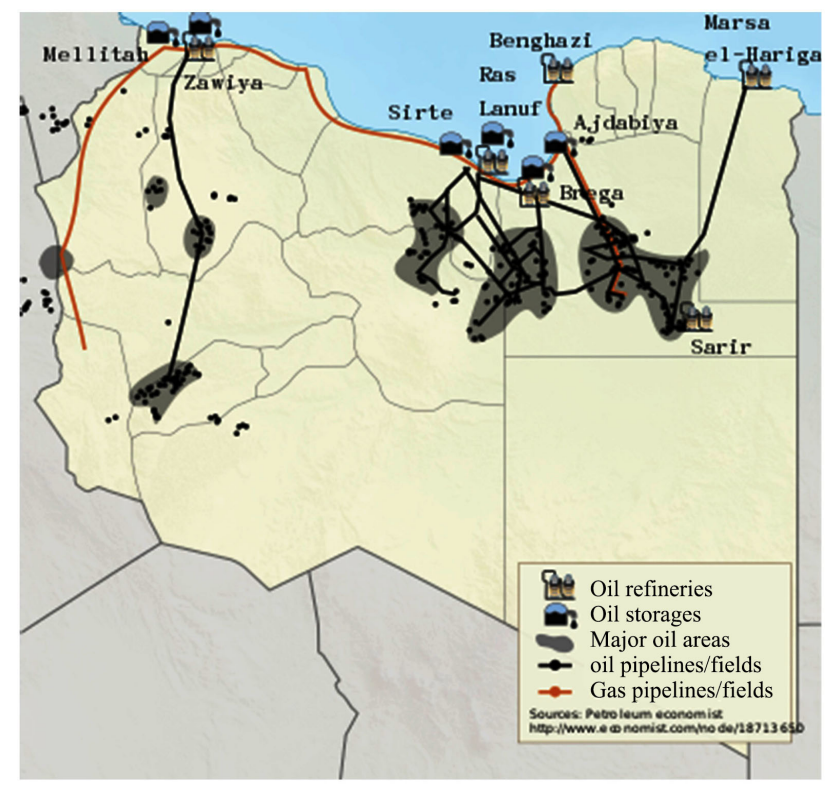

Figure 2. Libya's oil map.

\subsection{Libya's Oil}

Libya's oil reserves are the largest in Africa, ranking ninth among 10 countries with the world's largest proven oil reserves with an estimated rate of 46.4 billion barrels $(7.38 \times 109$ cubic meters) by 2010 . The average daily production during 2010 was 1.65 million barrels $(262 \times 103$ cubic meters/day), where reserves are estimated to last for 77 years if production continues at the current rate and unless new oil wells are discovered. Libya is an attractive region due to the cost of oil production (up to a dollar a barrel in some fields) and its proximity to European markets. The Libyan state faces a challenge to keep production in full-grown fields while exploring and developing discovered fields. The majority of Libyan territory remains undiscovered as a result of previous sanctions and disputes with foreign oil companies. Most of the Libyan oil (85\%) is exported to European markets. Libya's oil exports to the EU until 2010 were $11 \%$ or 403 million barrels making it the third largest source after Norway and Russia [10]. The cumulative production rate during 2009 was 27 billion barrels, which constitutes $65 \%$ of the reserve. Libya began oil exploration after the oil law of 1955 . The National Oil Corporation (NOC) is Libya's largest oil company and is responsible for exploration and export contracts [11].

\subsection{EOR Methods}

Many EOR methods have been used in the past, with varying degrees of success, for the recovery of light and heavy oils as well as tar sands. A general classification of these methods is shown in Figure 3 [12] [13]. Thermal methods are primarily intended for heavy oils and tar sands, although they are applicable to light oils in special cases. Non-thermal methods are normally used for light oils. Some of these methods have been tested for heavy oils; however, have had limited suc- 
cess in the field. Above all, reservoir geology and fluid properties determine the suitability of a process for a given reservoir. Among thermal methods, steam-based methods have been more successful commercially than others. Among non-thermal methods, miscible flooding has been remarkably successful, but the applicability is limited by the availability and cost of solvents on a commercial scale. Chemical methods have generally been uneconomic in the past, but they hold promise for the future. Among immiscible gas injection methods, $\mathrm{CO} 2$ floods have been relatively more successful than others for heavy oil [14].

\section{Concentrating Solar Power Plants (CSP)}

CSP plants provide energy with high temperatures which is used to run conventional power cycles such as the steam turbine, gas turbine and Sterling engine. Although CSP plants are used mostly for electricity generation, they can be used in many industrial applications. There are many different applications for CSP systems. One of the most important boundaries for choosing the most suitable technique for any proposed application is the operating temperature. For example, in applications which are used to run temperature is above $600^{\circ} \mathrm{C}$, the suitable technique is the central solar tower [15]. Other systems include:

- Solar tower system.

- Parabolic dish-engine.

- Liner Fresnel system.

- Parabolic trough system.

The advantages of Glass Point's technology (enclosed trough technology) over other solar designs are that, Glass Point technology is the only solar thermal design that provides the following:

- Delivering steam at costs competitive with natural gas. Because it covers more space (about 98\% of land coverage), as shown in Figure 4.

- Proven to withstand harsh oilfield environment.

- Equipped with a proven, automated washing system.

- Developed using oilfield best practices [16].

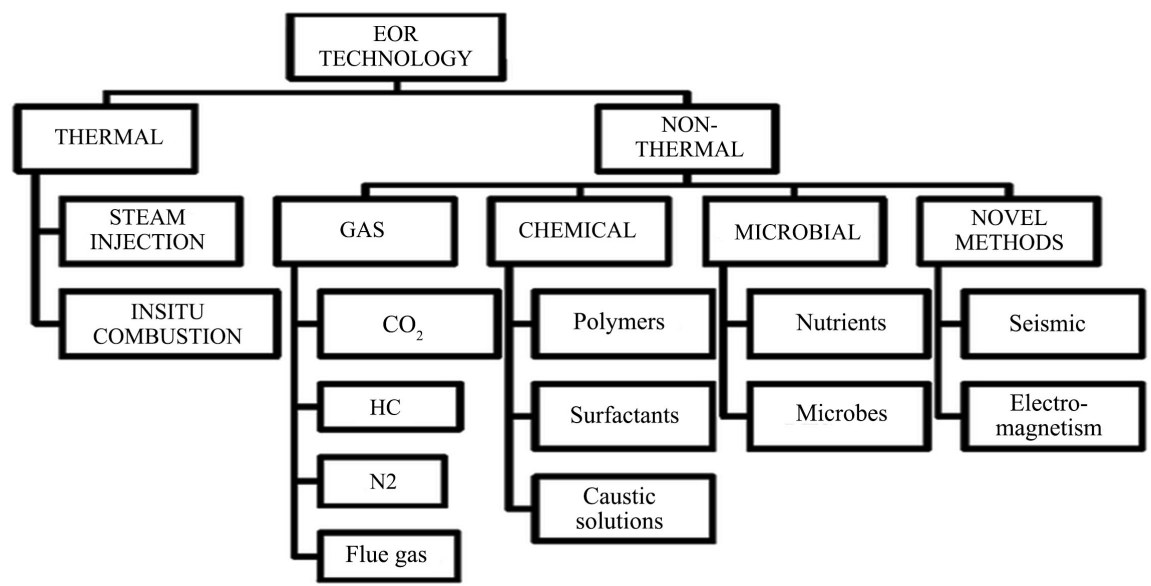

Figure 3. Classification of EOR methods. 

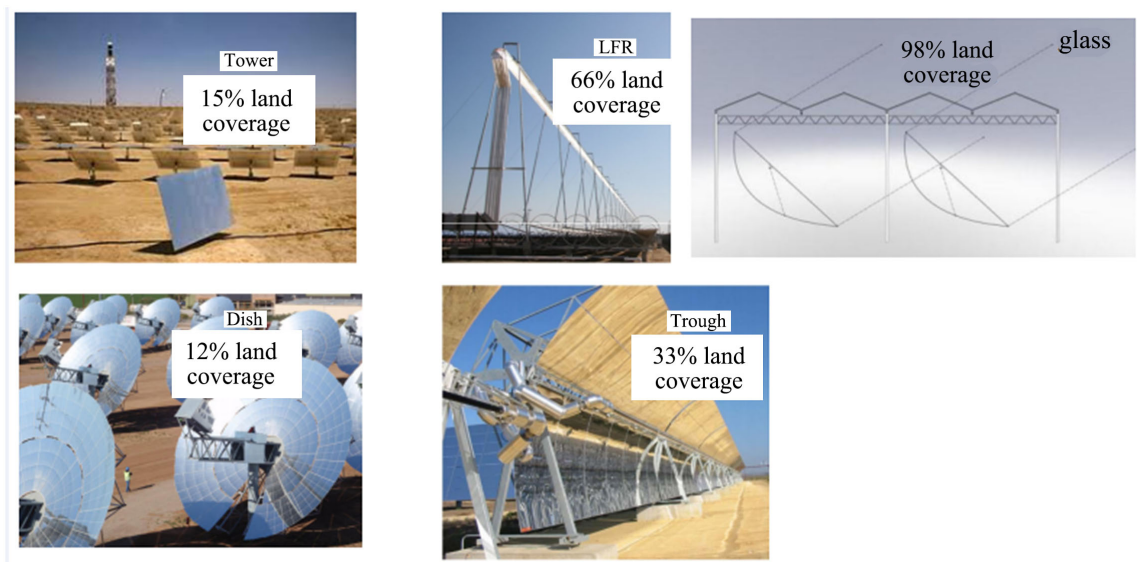

Figure 4. Types of concentrated solar collector [17].

\section{Parabolic Trough Technologies Applied}

In solar thermal power plants, the collectors are usually used to generate steam to power a thermodynamic cycle. The steam can be generated directly into the absorber tube. This technique is called Direct Steam Generation (DSG). Another technique is the use of a Heat Transfer Fluid (HTF) to transport solar thermal energy from the collectors to a heat exchanger where steam is generated. Enclosed trough represents an entirely new approach to the design and construction of concentrating solar collectors [18] [19]. The Enclosed trough system is protected by a glass-skinned structure, essentially a simplified agricultural greenhouse. The subject plant has a solar field footprint of $17,280 \mathrm{~m}^{2}$ with a peak output of over $7 \mathrm{MW}$ thermal. Referring to Figure 5, lightweight parabolic troughs are suspended within the glasshouse. The agricultural greenhouse industry has delivered over 30,000 hectares of glasshouse systems over the last few decades, and they are installed worldwide over a wide range of climates. They are available at low cost, and by providing structural support and isolating the solar collectors from wind and moisture, substantially reduce the total cost of the solar energy system.

\section{Methodology of the Study}

Libya is located between latitudes $20^{\circ} \mathrm{N}-39^{\circ} \mathrm{N}$ and longitude $10^{\circ} \mathrm{E}-25^{\circ} \mathrm{E}$ at the center of North Africa. 88\% of Libya's area is desert. According to the Institute of Thermodynamics Engineering, Germany, the direct natural solar radiation varies from $1900 \mathrm{kWh} / \mathrm{m}^{2}$ a year in the northern part of the country up to 2800 $\mathrm{kWh} / \mathrm{m}^{2}$ a year in the south-eastern Part [20]. Since concentrated solar power collectors are only economically applicable in regions where the solar radiation is up $1800 \mathrm{Kw} / \mathrm{m}^{2}$ a year [21]; therefore, all the regions of Libya meet values that are higher than this value of solar radiation unlike the southern parts of the country. The plant is expected to produce $70 \mathrm{GW} /$ year, and the design details are illustrated in Table 1 and Figure 7. The plant was supposed to operate on a VP-1 Thermion heat transfer fluid as a heat transfer fluid. 


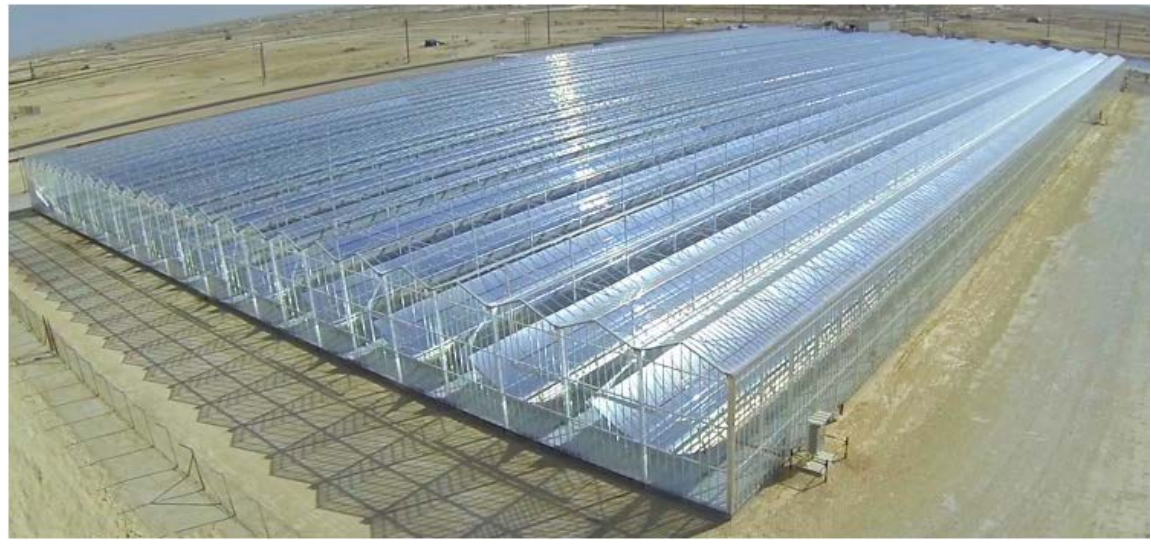

Figure 5. Photo of the enclosed trough system facility installed in the Amal oil field, Oman [17].

Table 1. Design parameters of the proposed parabolic trough power plant by SAM program.

\begin{tabular}{|c|c|}
\hline Characteristics & Value \\
\hline Total plant capacity & $25 \mathrm{MW}$ \\
\hline Total land area & $280 \times 188 \mathrm{~m}$ \\
\hline Steam delivered & $\begin{array}{c}958 \text { barrels of steam per day } \\
152 \text { tons of steam per day }\end{array}$ \\
\hline Number of loops & 17 \\
\hline Single loop aperture & $5248 \mathrm{~m}^{2}$ \\
\hline Solar multiple & 2 \\
\hline Number of washes per year & 63 \\
\hline Rated cycle conversion efficiency & $35 \%$ \\
\hline Water usage per wash & $0.7 \mathrm{~L} / \mathrm{m}^{2}$ aperture \\
\hline Row spacing & $15 \mathrm{~m}$ \\
\hline Number of field & 2 \\
\hline Receiver type & Schott ptr 80 \\
\hline Absorber tube inner diameter & $0.076 \mathrm{~m}$ \\
\hline Absorber tube out diameter & $0.08 \mathrm{~m}$ \\
\hline Absorber material type & $304 \mathrm{~L}$ \\
\hline HTF type & $\mathrm{Vp}^{-1}$ \\
\hline Design loop outlet temperature & $293^{\circ} \mathrm{C}$ \\
\hline Design loop inlet temperature & $391^{\circ} \mathrm{C}$ \\
\hline Full load hours & $6 \mathrm{~h}$ \\
\hline Storage type & Tow tank \\
\hline Storage fluid & Hitec solar salt \\
\hline Tank diameter & $17.0369 \mathrm{~m}$ \\
\hline Tank height & $20 \mathrm{~m}$ \\
\hline
\end{tabular}


Libya the measures that effect evaluating the practicability of founding a site for the utilizing concentrated solar technology is the annual conditions of the weather. A location, at $32.19^{\circ}$ longitude north and $20.15^{\circ}$ latitude east, on the northern coast of Libya was nominated for the study because of the strength of the solar radiation at it. The conditions of the study were at temperature of $24.7^{\circ} \mathrm{C}$ and mean wind speed of $3.4 \mathrm{~m} / \mathrm{s}$, and the evaluation was done by using SAM software [22]. The average energy that is resulted at that location a month is shown in Figure 6.

Figure 7 shows the layout of the solar steam plant system including its components. This layout uses the two-tank direct thermal energy storage. This Process Flow diagram incorporates a heat transfer fluid heater for preheating the fluid before entering the solar collector field. The system could also be designed without the Heat Transfer Fluid heater, and pump (P1) whose objective is to pump the Heat Transfer Fluid up to the collector field. The cold tank of the storage provides the cold Heat Transfer Fluid to the solar collector loop and receives the cold Heat Transfer Fluid after it has gone through the steam generator. Furthermore, the hot tank provides hot Heat Transfer Fluid to the steam generator and receives hot fluid from the collector loop. The hot tank may also provide Heat Transfer Fluid to the cold tank if the temperature of the fluid in the hot tank is lower than what is needed in order to produce steam, thus the need for the hot tank to cold tank pump (P5). This pump delivers cooled thermal oil from the hot tank to the cold tank where it can be pumped into the collector loop again to regain heat.

\section{Estimation of Thermal Energy Output}

The thermal energy produced by the power plant a year was 219 GWh with an efficiency of 35\%, as shown in Figure 8. There are losses in energy due two reasons that are solar energy losses in the field and power block. The solar field losses can be shown in forms of optical losses in the solar collectors and other components such as receivers and piping; however, the losses due to power block can be represented in mechanical, and thermal losses that happen due to running supplementary equipment.

\section{Economic Advantages of Solar EOR}

Solar EOR can decrease the amount of gases by up to $80 \%$ that can be used for other applications such as electricity generation, desalination. The economic results of this project were studied on the basis of the thermal power produced. The cost of energy use was calculated using the annual project direct costs, including solar collectors, receivers and heat energy storage costs, as well as indirect project costs such as engineering and construction costs. The simulation results show that the actual cost of the proposed plan was $6 \$ / \mathrm{KW}$, and the contribution of each component of the plant in this total amount is illustrated in Figure 9 [23]. Comparing this value with the basic cost of the concentrated solar Collectors, the value is approximate and is the lowest for the other collectors as 
in Figure 10. It can be noted that the total half-cost of Levelized Cost of Energy (LCOE) contributes to solar energy with the storage capacity of the thermal energy at the same cost ratio at a rate of $50 \%$ of the cost of the plant.

\section{Environmental Benefits of Solar EOR}

Solar EOR's steam generation process has zero emissions. Solar EOR helps to reduce the quantity of nitrogen oxides and carbon dioxides in the atmosphere. Solar EOR technology has significant environmental economic benefits unlike conventional technology. Also, in terms of the environment, SEOR can reduce the emissions of EOR to $0.1 \mathrm{~g} \mathrm{CO}_{2} / \mathrm{MJ}$ [24] [25].

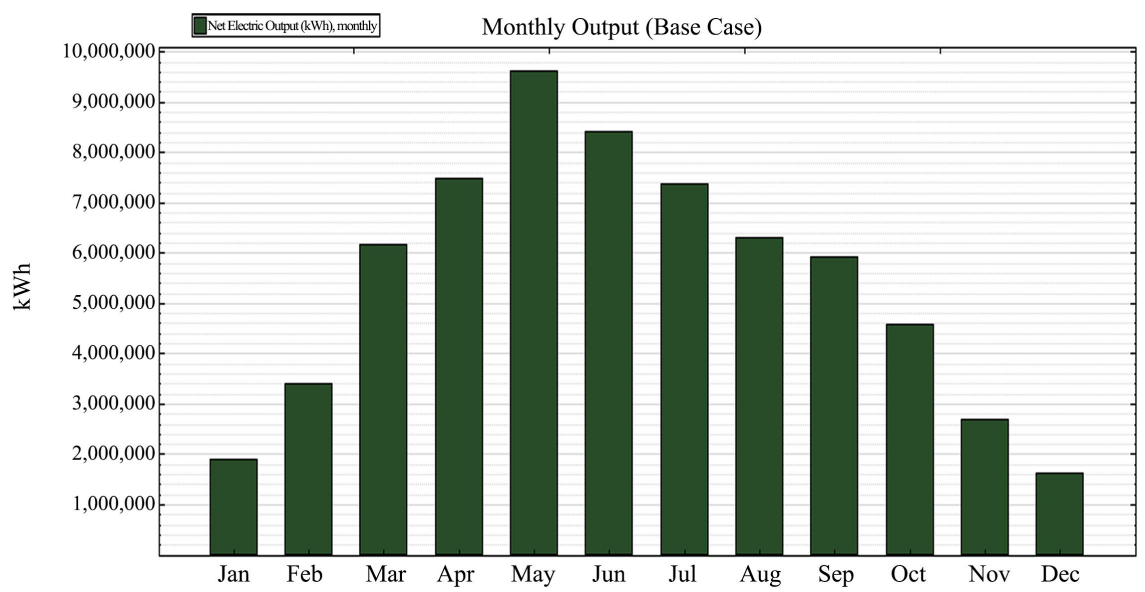

Figure 6. The average monthly of solar energy.

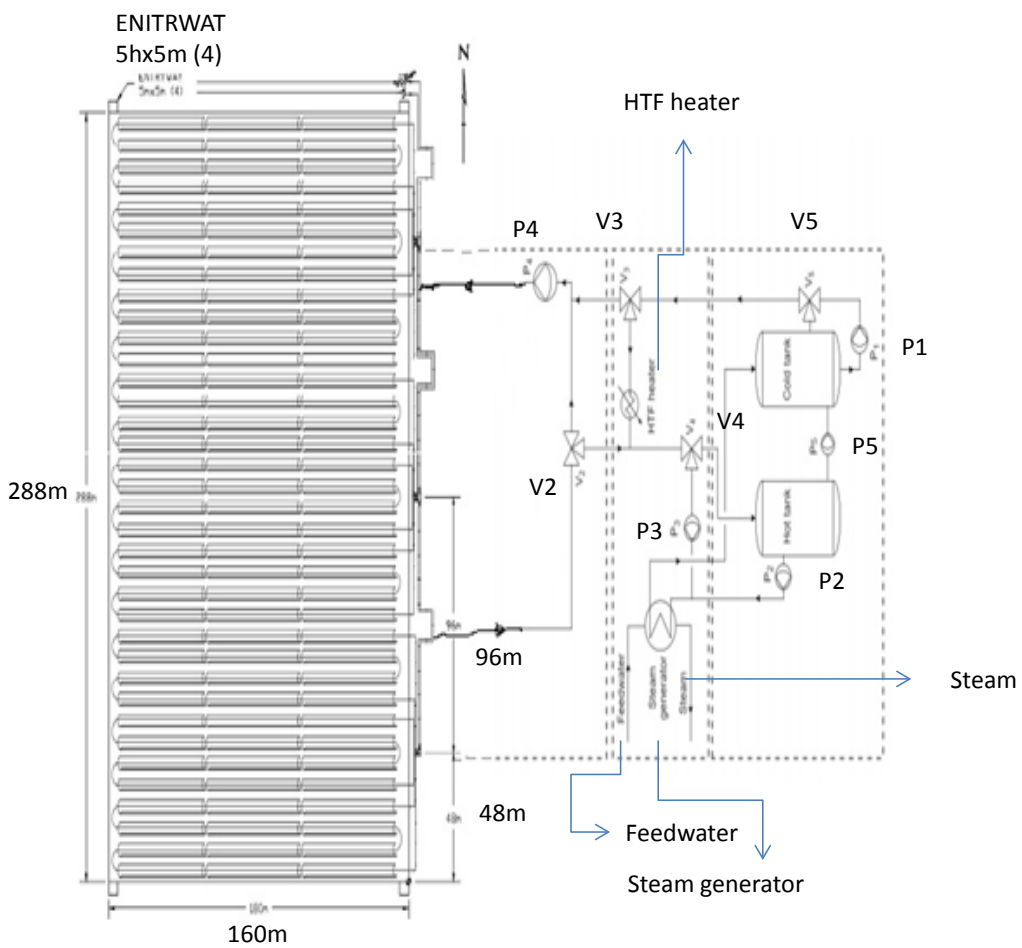

Figure 7. Layout and process flow diagram of the plant. 


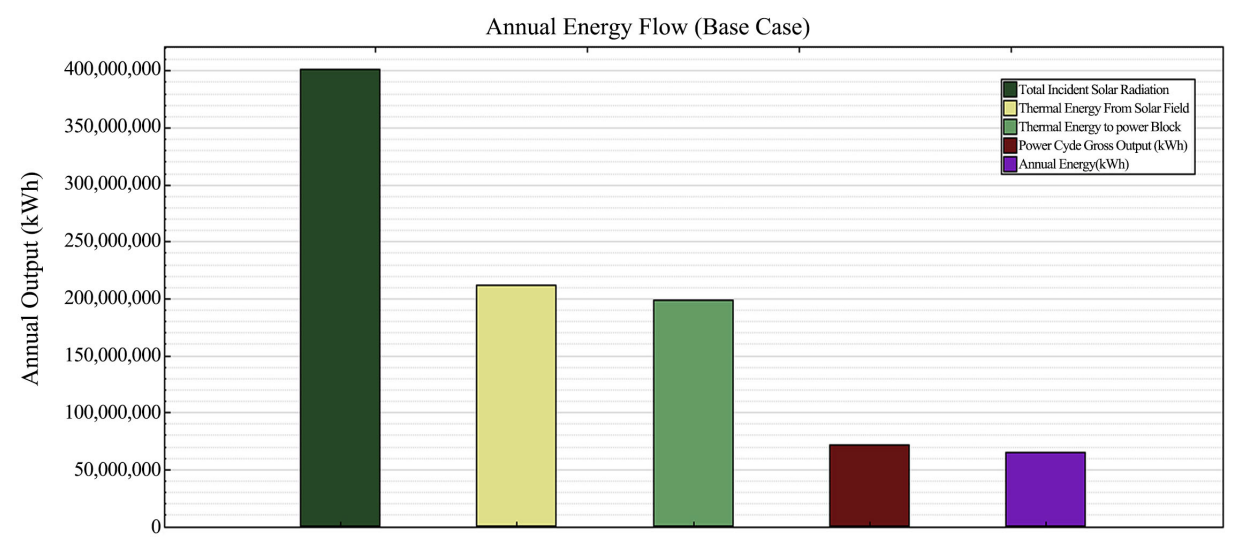

Figure 8. The amount of annual energy produced.

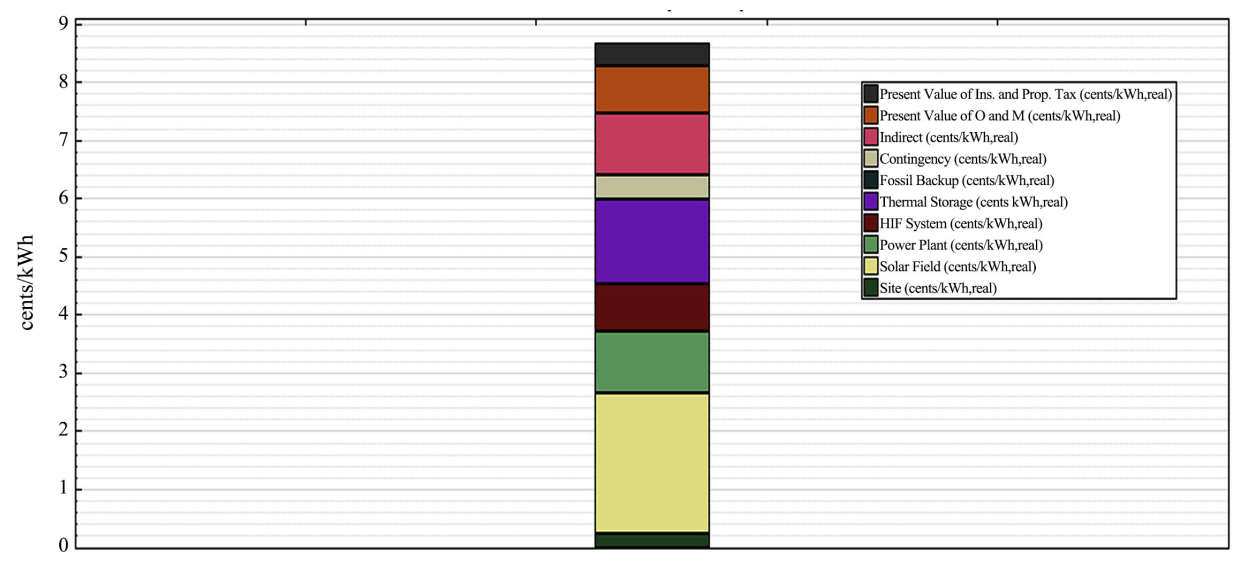

Figure 9. Total cost of the system.

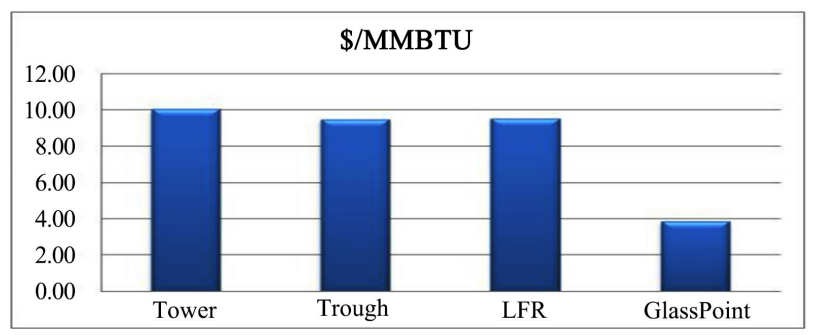

Figure 10. Comparing cost of the concentrated solar collectors [17].

\section{Conclusion}

In this study, the feasibility of integration of the upstream oil supply with renewable energy was presented. Solar energy was found to be the best source of renewable energy to be integrated into oil and gas industry. Hence, different types of solar energy technologies were studied. In addition, solar energy was evaluated for producing part of the energy requirement of the oil production process. Challenges in implementing such integration were outlined. A case study was carried out with the focus on Libya, to demonstrate the application of this study. From this study, it was observed that the integration of solar energy into oil and gas upstream operations was technically possible. Glass Point technology, supported 
by a good storage system, was a good example of solar integration operations for steam generation purposes. Significant amounts of $\mathrm{CO}_{2}$ emissions, gas combustion and cooling water can be saved through this type of solar energy integration. Solar integration has financial advantages on the oil operations and can extend the life of the oil reservoir.

\section{Recommendations}

Since a number of challenges facing solar energy integration in Libya including technical, practical, economical, and institutional considerations, other studies could be carried out in future to address these challenges besides their solutions.

\section{Conflicts of Interest}

The authors declare no conflicts of interest regarding the publication of this paper.

\section{References}

[1] Sharma, A. (2011) A Comprehensive Study of Solar Power in India and World. Renewable \& Sustainable Energy Reviews, 15, 1767-1776. https://doi.org/10.1016/j.rser.2010.12.017

[2] Mekhilef, S., Saidur, R. and Safari, A. (2011) A Review on Solar Energy Use in Industries. Renewable \& Sustainable Energy Reviews, 15, 1777-1790.

https://doi.org/10.1016/j.rser.2010.12.018

[3] Brabant, D. (2016) AGAT Laboratories.

[4] Aye, L. (2015) Lecture-Solar Energy at University of Melbourne.

[5] Bright Source (2012) Coalinga Enhanced Oil Recovery Project. http://www.brightsourceenergy.com/coalinga\#.V1H5ePnhCUl

[6] Glass Point (2015) PDO Pilot. http://www.glasspoint.com/pdo-amalpilot

[7] PDO Solar Steam Pilot Case Study, 2015.

[8] Hossain, M.E., Mousavizadegan, S.H. and Islam, M.R. (2008) The Effects of Thermal Alterations on Formation Permeability and Porosity. Petroleum Science and Technology, 26, 1282-1302. https://doi.org/10.1080/10916460701834028

[9] Kaye, S.E., Ting, V.C. and Fair, I.C. (1982) Development of a System to Utilize Flue Gas from Enhanced Oil Recovery Combustion Projects. Journal of Petroleum Technology, 34, 181-188. https://doi.org/10.2118/8360-PA

[10] European Commission Directorate-General for Energy (2011) Registration of Crude Oil Imports and Deliveries in the European Union (PDF). Market Observatory for Energy.

[11] Wad dams Frank, C. (1980) The Libyan Petroleum Law of 1955. The Libyan Oil Industry. Croom Helm Series on the Arab World. Taylor \& Francis, Hoboken.

[12] Ali, S.M.F. and Thomas, S. (1989) The Promise and Problems of Enhanced Oil Recovery Methods. Technical Meeting/Petroleum Conference of the South Saskatchewan Section, Regina, 25-27 September 1989, 1-11. https://doi.org/10.2118/SS-89-26

[13] Amarnath, A. (1999) Enhanced Oil Recovery Scoping Study. An Electric Power Research Institute (EPRI) Report. 
http://www.energy.ca.gov/process/pubs/electrotech_opps_tr113836.pdf

[14] Olajire, A.A. (2014) Review of ASP EOR (Alkaline Surfactant Polymer Enhanced Oil Recovery) Technology in the Petroleum Industry: Prospects and Challenges. Energy, 77, 963-982. https://doi.org/10.1016/j.energy.2014.09.005

[15] Elmnifi, M., Amhamed, M., Abdelwanis, N. and Imrayed, O. (2017) Solar Supported Steam Production for Power Generation in Libya. Acta Mechanical Malaysia, 2, 5-9. https://doi.org/10.26480/amm.02.2018.05.09

[16] Quaschning, V. (2003) Solar Thermal Power Plants. Renewable Energy World, 6, 109-113.

[17] http://www.glasspoint.com

[18] Romero-Alvarez, M. and Eduardo, Z. (2007) Concentrating Solar Thermal Power. Taylor \& Francis Group, Hoboken.

[19] Fabian, F.J. (2012) Direct Steam Generation (DSG) - Technology Overview. SFERA Summer School. Almerá (Spain), 28 June.

[20] Kaygusuz, K. (2011) Prospect of Concentrating Solar Power in Turkey: The Sustainable Future. Renewable and Sustainable Energy Reviews, 15, 808-814. https://doi.org/10.1016/j.rser.2010.09.042

[21] Blair, N., et al. (2014) System Advisor Model: General Description. https://doi.org/10.2172/1126294

[22] (2013) System Advisor Model (SAM). https://sam.nrel.gov

[23] BG Group (2014) Global Energy Market Outlook 2014/15.

[24] Brandt, A.R. and Unnasch, S. (2010) Energy Intensity and Greenhouse Gas Emissions from Thermal Enhanced Oil Recovery. Energy Fuels, 24, 4581-4589. https://doi.org/10.1021/ef100410f

[25] Sandler, J., et al. (2014) Solar-Generated Steam for Oil Recovery: Reservoir Simulation, Economic Analysis, and Life Cycle Assessment. Energy Conversion and Management, 77, 721-732. https://doi.org/10.1016/j.enconman.2013.10.026 